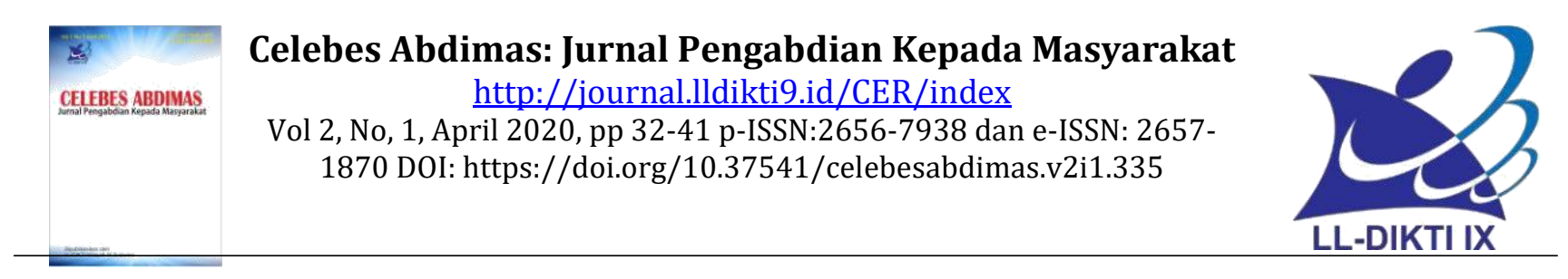

\title{
Penerapan Latihan Model Dhin Dhon Pada Klub Bolavoli di Kabupaten Bantaeng
}

\author{
Sahabuddin 1 , Hikmad Hakim 2 \\ 1Pendidikan Kepelatihan Olahraga, Universitas Negeri \\ Makassar Email: sahabuddin@unm.ac.id \\ 2Pendidikan Kepelatihan Olahraga, Universitas Negeri Makassar \\ Email: hikmad.hakim@unm.ac.id
}

\section{Artikel info}

Article history:

Received: Februari-2020

Revised: Februari-2020

Accepted: Maret-2020

Publish: April-2020
Abstract. This service aims to socialize and implement dhin dhon model exercises at the volleyball club in Bantaeng Regency. This community service is one part of the Tri darma of higher education that is required for Lecturer staff at Makassar State University. The object of this service is the volleyball athlete in Bantaeng Regency. The implementation technique of the socialization and application of dhin dhon training for athletes is through the provision of theory and practice of the forms of dhin dhon training model movements and other related sciences in this community service. The implementation of socialization activities under the model of passing exercises (dhindhon) in the volleyball game in Bantaeng Regency can be concluded as follows: (1) In general, the socialization participants were very enthusiastic in accepting the material provided both in theory and practice, (2) Participants could realize that for get maximum skills or skills required training programs with a variety of methods and models of training that are carried out systematically and programmed, and (3) The dissemination of the model of passing training (dhindhon) in the game of volleyball is very helpful to achieve technical skills to the maximum which is only done conventionally without the creativity and innovation of each exercise.

Abstrak. Pengabdian ini bertujuan untuk mensosialisasikan dan menerapkan latihan model dhin dhon pada klub bolavoli di Kabupaten Bantaeng. Pengabdian masyarakat ini adalah salah satu bagian dari pada Tri darma perguruan tinggi yang diwajibkan bagi staf Dosen di Universitas Negeri Makassar. Objek dari pengabdian ini adalah atlet bolavoli di Kabupaten Bantaeng. Teknik pelaksanaan dari pada sosialisasi dan penerapan latihan dhin dhon bagi atlet adalah melalui pemberian teori dan praktek tentang bentuk-bentuk gerakan latihan model dhin dhon serta ilmu pengetahuan lain yang terkait dalam pengabdian masyarakat ini. Pelaksanaan kegiatan sosialsiasi model latihan passing bawah (dhindhon) dalam permainan bolavoli di Kabupaten Bantaeng dapat ditarik kesimpulan sebagai berikut: (1) Pada umumnya peserta sosialisasi sangat antusias dalam menerima materi yang diberikan baik secara teori 
Keywords:

Latihan; Model

Dhin Dhon;

Bolavoli. maupun praktek, (2) Peserta dapat menyadari bahwa untuk mendapatkan keterampilan atau skill yang maksimal dibutuhkan program latihan dengan berbagai metode dan model latihan yang dilakukan secara sistematis dan terprogram, dan (3) Adanya sosialisasi model latihan passing bawah (dhindhon) dalam permainan bolavoli sangat membantu untuk mencapai keterampilan teknik secara maksimal yang selama hanya dilakukan secara konvensional tanpa adanya kreatifitas dan inovasi setiap latihan.

Coresponden author:

Sahabuddin

Pendidikan Kepelatihan Olahraga, Universitas Negeri Makassar Email: sahabuddin@unm.ac.id

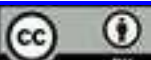

artikel dengan akses terbuka dibawah lisensi CC BY -4.0

\section{PENDAHULUAN}

Teknik passing bawah merupakan salah satu teknik dasar bolavoli yang sangat pentimg. Mengenai pentingnya passing, Nasin El-Kabumaini dan Anno D. Sanjari (2011:33) mengemukakan pendapatnya sebagi berikut. "Teknik dasar passing dilatihkan guna membangun serangan dalam permainan bolavoli, dan samangat diperlukan saat tim menghadapi lawan yang kuat guna membangun defensive yang kuat buat tim". Program latihan dalam mempraktikkan variasi dan kombinasi teknik dasar dengan latihan fisik untuk mengkoordinasi yang baik. Dalam ruang lingkup permainan bola besar salah satunya adalah bolavoli dengan berbagai teknik dasar di dalamnya. Seperti servis, passing atas, passing bawah, dan smash. Passing bawah adalah cara memukul bola dengan ayunan kedua lengan secara bersamaan ke arah datangnya bola dan disaat bola mengenai kedua lengan lutut kaki diluruskan. Ketika melakukan passing bawah kearah depan, ayunan lengan pada saat bola mengenai kedua lengan tidak lebih dari 900 dengan bahu atau badan. Hal tersebut sebenarnya sudah menjadi awal yang sangat baik dalam materi latihan bolavoli, ketika keinginan yang besar dimiliki oleh atlet maka transfer ilmu yang dilakukan bisa lebih efektif. Namun, latihan bolavoli bisa menjadi kurang efektif dan menyenangkan bahkan membuat atlet merasa kesulitan melakukan latihan ini disebabkan kurangnya kreatifitas pelatih dalam membuat model latihan yang menarik bagi atlet, akan tetapi tetap efektif dalam mencapai tujuan yang dirancang dalam setiap latihan. Jim Lavin (2008:5) menyatakan "Every child is capable of being creative. However, when pupils are forced to suppress their creativity by participating in an activity they dislike or which does not motivate them, then their response can lead to inappropriate behavior". Pernyataan tersebut menjelaskan bahwa setiap anak memiliki kemampuan dalam mengembangkan kreativitas, tetapi ketika anak dipaksa untuk menekankan kreativitas mereka dengan berpasrtisipasi dalam suatu kegiatan yang tidak disukai atau yang tidak memotivasi mereka, maka kreativitas sulit untuk dimunculkan. Pada kejadian ini faktor pelatih sangatlah penting dalam pengembangan diri seorang atlet. Pada latihan bolavoli jika seorang pelatih kurang dalam mengembangkan kreativitas maka atlet kurang memiliki minat dalam mengikuti latihan, apalagi bagi atlet yang pernah mengalami trauma cedera. Untuk itu seorang pelatih harus mampu melaksanakan tugas dan mengadopsi model latihan baru yang dapat membantu masalah atlet dalam mencapai tujuan latihan, khususnya pada materi passing bawah. Hal inilah yang terkadang sulit untuk diwujudkan oleh para pelatih. Kelemahan dalam latihan sering terjadi pada pengembangan model yang monoton, sehingga membuat atlet mengalami kejenuhan dalam mengikuti latihan. Masih banyak pelatih yang menggunakan gaya tradisional atau konvensional, sehingga atlet kurang memiliki kebebasan dalam melakukan keterampilan gerak secara maksimal. Inilah yang terjadi pada atlet di Club Kabupaten Bantaeng, pelatih belum menggunakan model latihan serta belum mengoptimalkan kreatifitas yang dimiliki, sehingga atlet dalam mengikuti latihan mengalami 
kejenuhan. Oleh sebab itu, atlet memilih untuk bermain-main dengan atlet yang lain sehingga materi yang akan disampaikan oleh pelatih kurang dicapai secara maksimal oleh atlet. Ketertarikan atlet dalam mengikuti kegiatan latihan bolavoli masih rendah, khususnya pada materi passing bawah sehingga hasil yang diperoleh kurang maksimal. Oleh karena itu, untuk mengatasi hal tersebut harus ada upaya dalam mengatasinya yaitu dengan cara menggunakan pengembangan model. Peneliti menggunakan materi passing bawah dengan model-model yang lebih menarik dan menyenangkan untuk atlet. Maka dari itu, lebih memilih mengembangkan model passing bawah di tingkat atlet yang disesuaikan dengan karakteristik atlet. Latihan bolavoli untuk atlet telah sampai pada pengembangan keterampilan, maka dalam latihan nantinya atlet akan melakukan model passing bawah pada latihan teknik passing bawah dengan mengkombinasikan latihan fisik dalam permainan bolavoli yang dikemas dengan istilah model dhin dhon. Melalui pengembangan model passing bawah dhin dhon diharapkan dapat membantu atlet dalam meningkatkan keterampilan passing bawah menjadi lebih baik. Serta dapat digunakan sebagai tantangan untuk pelatih, terutama pada saat memberikan materi passing bawah melalui pengembangan model passing bawah. Tidak hanya itu, tetapi atlet juga dapat memperhatikan secara antusias dan merasa senang dengan tidak jenuh ketika mengikutinya. Sehingga nantinya dalam menggunakan model-model ini pelatih bisa menyelaraskan dengan kondisi dan situasi yang dihadapi oleh atlet. Pembuatan model pengembangan yang tepat di dalam materi passing bawah yang tentu saja gerakannya harus mendukung dan berhubungan dengan passing bawah (permulaan, perkenaan, dan gerakan lanjutan). Terkait dengan pernyataan-pernyataan yang telah dikemukakan pada bagian terdahulu, maka hal tersebut menunjukkan bahwa perlu dikembangkan model passing bawah dalam permainan bolavoli, yang nantinya dapat dijadikan sebagai solusi untuk memudahkan atlet dalam belajar passing bawah secara lebih efektif. Penggunaan teknik passing merupakan modal dasar untuk bisa bermain bolavoli karena passing dan umpan adalah pukulan bola pertama setelah bola itu berada dalam permainan akibat dari serangan, servis lawan, atau permainan net. Arah bola ditujukan kepada pengumpan atau penyerang regu. Passing lebih ditekankan untuk menerima dan mengoperkan bola kepada teman seregunya. Permainan bolavoli bisa berlangsung walaupun hanya menggunakan teknik passing semata tanpa teknik smash maupun block.

Program Pengabdian Kepada Masyarakat (PkM) berbasis Ipteks bagi Masyarakat (IbM) ini khalayak sasarannya adalah atlet-atlet bolavoli di Kabupaten Bantaeng yang merupakan pemain yang belum maksimal dalam bermain. Jumlah mitra ini ditetapkan dengan mempertimbangkan efisiensi dan intensitas pelaksanaan program. Mitra yang merupakan pemain-pemain muda klub bolavoli di Kabupaten Bantaeng. Jenis permasalahan yang ditangani dalam program IbM meliputi aspek penguasaan passing bawah bolavoli. Aspek penguasaan dengan melatih pemain-pemain dari berbai model passing bawah dengan menggabungkan teknik passing bawah dan latihan kondisi fisik. Pada hakekatnya, kegiatan IbM ini solusi terhadap permasalahan yang dihadapi mitra melalui pendekatan secara terpadu, agar dapat meningkatkan nilai efektifitas yang masih belum termanfaatkan secara optimal.

Adapun luaran yang dapat dicapai pada kegiatan ini adalah sebagai berikut: (1) Meningkatkan pengetahuan atlet dalam pembinaan teknik dan kondisi fisik pada skill teknik passing bawah permainan bolavoli khususnya pada atlet Club di Kabupaten Bantaeng, (2) Meningkatkan keterampilan dalam melakukan gerakan-gerakan yang ada dalam kombinasi teknik dan fisik bagi atlet club di Kabupaten Bantaeng, dan (3) Pelatih dapat mengaplikasikan pola latihan teknik fisik (dhin dhon) kedalam program latihan yang akan datang.

\section{Metode}

Pemberian materi pada atlet dan pelatih cabang olahraga bolavoli di Kabupaten Bantaeng adalah: (1) Teori latihan, (2) Teori teknik passing bawah dalam permainan bolavoli, (3) Teori kondisi fisik, dan (4) Biomekanika. Pada sesi praktek dalam program kemitraan masyarakat ini, yaitu dengan jalan mendemostrasikan pada atlet dan pelatih cabang olahraga 
bolavoli tentang model latihan passing bawah (dhindhon) dalam permainan bolavoli. Pengembangan model latihan diharapkan menjadi produk yang dapat dikembangkan secara sistematis dan logis, sehingga produk ini mempunyai keefektifan dan keefisienan yang layak digunakan. Adapun model latihan passing bawah yang dilaksanakan adalah:

Tabel 1. Materi model latihan dhin dhon yang direncanakan pada penelitian

\begin{tabular}{|c|c|c|}
\hline No. & Materi Model Latihan & Ket. \\
\hline 1. & Passing bawah kemudian push up & \\
\hline 2. & Passing bawah kemudian melakukan sit up & \\
\hline 3. & Passing bawah kemudian lateral lunge & \\
\hline 4. & Passing bawah kemudian butt kicks & \\
\hline 5. & Passing bawah kemudian melakukan alternating side steps & \\
\hline 6. & Passing bawah kemudian melakukan squat & \\
\hline 7. & Passing bawah kemudian melakukan cat walk & \\
\hline 8. & Passing bawah kemudian jumping jacks & \\
\hline 9. & Passing bawah kemudian squat side kick & \\
\hline 10. & Passing bawah kemudian melakukan forward lunges & \\
\hline 11. & Passing bawah kemudian kombinasi push up dan sit up & \\
\hline 12. & Passing bawah kemudian setengah roll ke belakang & \\
\hline 13. & $\begin{array}{l}\text { Passing bawah kemudian posisi push dan lengan melakukan gerakan } \\
\text { elbow plank secara bergantian }\end{array}$ & \\
\hline 14. & $\begin{array}{l}\text { Passing bawah kemudian posisi skip di tempat kemudian bergeser silang } \\
\text { ke kanan dan ke kiri }\end{array}$ & \\
\hline 15. & $\begin{array}{l}\text { Passing bawah kemudian posisi push dan tangan diangkat ke depan } \\
\text { secara bergantian }\end{array}$ & \\
\hline 16. & $\begin{array}{l}\text { Passing bawah kemudian posisi push dan tangan diangkat ke kiri dan } \\
\text { ke kanan }\end{array}$ & \\
\hline 17. & $\begin{array}{l}\text { Passing bawah kemudian posisi push dan melakukan gerakan opposite } \\
\text { leg and arm }\end{array}$ & \\
\hline 18. & Passing bawah kemudian posisi push dan melakukan gerakan climbers & \\
\hline 19. & $\begin{array}{l}\text { Passing bawah kemudian posisi push dan melakukan gerakan } \\
\text { mountain climbers / knee to elbow plank }\end{array}$ & \\
\hline 20. & $\begin{array}{l}\text { Passing bawah kemudian posisi push, badan lurus dan ke dua kaki } \\
\text { diangkat ke kiri dan ke kanan }\end{array}$ & \\
\hline 21. & $\begin{array}{l}\text { Passing bawah kemudian posisi push dan kaki melakukan gerakan } \\
\text { silang secara bergantian }\end{array}$ & \\
\hline 22. & $\begin{array}{l}\text { Passing bawah kemudian posisi push dan kaki melakukan gerakan } \\
\text { memutar ke bagian dalam secara bergantian }\end{array}$ & \\
\hline 23. & $\begin{array}{l}\text { Passing bawah kemudian posisi push dan melakukan gerakan plank } \\
\text { leg raised }\end{array}$ & \\
\hline 24. & $\begin{array}{l}\text { Passing bawah kemudian posisi push dan tangan memutar pada } \\
\text { posisi membalik badan secara bergantian }\end{array}$ & \\
\hline 25. & Passing bawah kemudian posisi push dan melakukan gerakan cobra stretch & \\
\hline
\end{tabular}

Kegiatan pengabdian kepada Masyarakat di klub bolavoli Kabupaten Bantaeng dilaksanakan pada bulan September - Oktober bertempat di lapangan Serui. Kegiatan yang dilaksanakan meliputi sosialisasi mengenai latihan passing bawah (dhindhon) dalam permainan bolavoli.

Kegiatan sosialisasi mengenai model latihan passing bawah (dhindhon) yang baik dilakukan melalui tahapan sebagai berikut:

\section{Tahap Persiapan}

a. Kegiatan survei tempat atau lokasi Pengabdian Kepada Masyarakat yaitu di kabupaten Bantaeng. 
b. Permohonan izin kegiatan Pengabdian Kepada Masyarakat kepada pengurus klub di Kabupaten Bantaeng

c. Pengurusan administrasi (surat-menyurat)

d. Persiapan alat dan bahan serta akomodasi

e. Persiapan tempat untuk sosialisasi model latihan yaitu menggunakan salah satu lapangan di kabupaten Bantaeng.

\section{Tahap Pelaksanaan}

a. Pembukaan dan perkenalan pada atlet-atlet bolavoli di Kabupaten Bantaeng.

b. Sosialisasi mengenai pengertian latihan, teori passing bawah bolavoli, latihan kondisi fisik dan biomekanika yang efektif dan efesien.

c. Sesi diskusi atau tanya jawab dengan atlet mengenai model latihan passing bawah (dhindhon) yang baik.

\section{Tahap Akhir (penutupun)}

a. Penyerahan bola voli kepada pelatih untuk dapat digunakan oleh atlet saat latihan.

b. Foto bersama dengan pelatih dan atlet.

c. Penyusunan laporan tentang model latihan passing bawah (dhindhon) dalam permainan bolavoli yang dilaksanakan di Kabupaten Bantaeng.

\section{Alat dan Bahan Kegiatan}

a. Alat kegiatan; Selama kegiatan pelatihan berlangsung membutuhkan beberapa alat guna memperlancar jalannya pelatihan. Adapun alat yang digunakan dalam kegiatan ini berupa: laptop, bola voli, kamera untuk eveluasi gerak dalam bentuk dokumentasi, stopwatch yang berfungsi sebagai alat pengaturan waktu dalam rangkaian pelaksanaan gerakan atlet, sempritan yang berfungsi sebagai aba-aba dalam memulai dan mengakhiri gerakan.

b. Bahan kegiatan; Bahan yang digunakan dalam pelatihan ini pada atlet dan pelatih cabang olahraga bolavoli diantaranya adalah: papan pengalas, kertas dan ballpoint untuk mencatat.

\section{Materi Umum}

Sebelum pelaksanaan secara praktek di lapangan tentang model latihan yang dilaksanakan, maka diberikan gambaran beberapa materi umum yang menjadi gambaran dalam model latihan passing bawah (dhindhon) dalam permainan bolavoli. Materi umum tersebut diantaranya adalah:

a. Teori latihan

Dalam proses latihan hendaknya pelatih memperhatikan hal-hal penting atau prinsipprinsip dalam latihan, dimana ada beberapa aturan yang tidak boleh dilanggar dan perlu dipahami oleh pelatih, diantaranya: (1) 1. Perkembangan Multilateral, (2) Partisipasi Aktif, (3) Individual, (4) Overload, (5) Spesifikasi, (6) Kembali Asal/pulih asal, dan (7) Variasi. Prinsip perkembangan multilateral dimana, fondasi dari suatu bangunan latihan yang bagus maka akan kokoh, begitu juga dengan pengoptimalan kemampuan multilateral bagi atlet khususnya pada usia 6 s.d 15 tahun akan membawa dampak yang signifikan nantinya pada keberhasilan gerak atau keluasan gerak yang dimiliki pada jenjang level atlet elit. Jika kemampuan multilateral seorang atlet kurang bagus, maka kendala untuk penguasaan teknik tinggi akan mengalami kendala. Untuk prinsip partisipasi aktif, disini menuntut kerjasama yang bagus antara usaha maksimal dari atlet dengan kerja keras pelatih, dengan latihan yang kontinyu. Prinsip individual intinya adalah masing-masing atlet merupakan individu yang berbeda-beda baik dilihat dari (1) gen/keturunannya (sifat, mental dan emosi), (2) Umur perkembangan (biologis), dan (3) Umur latihan (tergantung masa latihan). Prinsip overload atau beban lebih, yaitu beban latihan hendaknya selalu meningkat, namun disesuaikan peningkatannya, melihat dengan perkembangan kemampuan atlet baik fisik, teknik maupun mental, dan yang paling penting jangan sampai terjadi over training. Prinsip selanjutnya yaitu spesifikasi, dimana dalam prinsip ini pada usia tertentu maka sebaiknya atlet dikhususkan dengan cabang olahraga yang sesuai dengan kemampuan atau skill yang dimiliki, agar fokus. Prinsip kembali asal atau pulih asal, biasanya prinsip ini berlaku manakala atlet sudah tidak mau berlatih secara kontinyu lagi, atau terjadi vacum latihan, sehingga organ-organ tubuh dan kemampuan vasculer akan mengalami 
penurunan dan kembali seperti sediakala sebelum latihan. Prinsip terakhir yaitu variasi latihan, disini menuntut pelatih dan tim harus mampu mengkreasikan suatu latihan yang menarik bagi atlet, hal ini sangat penting agar atlet tidak bosan dengan pelatih. Suatu latihan hendaknya memiliki tujuan atau sasaran yang terukur dan jelas, berikut sasaran dalam latihan yang hendaknya bisa tercapai: (1) Perkembangan fisik multilateral, (2) Perkembangan fisik khusus,

(3) Faktor teknik, (4) Faktor taktik, (5) Aspek psikologi, (6) Faktor kesehatan, dan (7) Pencegahan cidera. Sasaran latihan merupakan sasaran latihan yang harus bisa diukur dan dicapai secara jelas dalam latihan. Banyak pelatih bagus dalam setiap cabang olahraga, namun masih sangat sedikit pelatih yang memiliki catatan latihan secara khusus tentang perkembangan dan juga hasil dari latihan yang sudah dilakukan. Hal tersebut juga menjadi kelemahan beberapa pelatih. Pencegahan cedera merupakan sasaran utama bagi pelatih, dimana sebagus apapun atlet, namun jika dia dirundung cedera yang berkepanjangan maka akan tidak berguna atau percuma latihan yang dilakukan tersebut. Sehingga pelatih mutlak harus mendesain bagaimana latihan yang save dan juga tetep berkualitas. Disini penulis hanya berbagi tentang konsep latihan, namun hal yang terpenting dalam latihan adalah "trial and error" dalam batas kewajaran pada suatu latihan itu harus berani dilakukan, jika kita tidak berani mencoba dan juga langsung praktek melatih di lapangan (hanya membaca teori) maka kemungkinan kecil kita dapat berhasil dalam melatih. Hal tersebut dilandasi dengan kondisi dan situasi di lapangan sangat heterogen, sehingga pengalaman pelatih dalam melatih sangat dipengaruhi oleh kebijakan dan pengambilan keputusan yang diambil saat terjadi masalah di lapangan.

b. Teori teknik passing bawah dalam permainan bolavoli

Kegiatan olahraga perlu ditumbuh kembangkan kembali dan disebar luaskan secara menyeluruh agar diketahui, dipelajari dan dipraktekkan oleh atlet. Untuk menciptakan suasana latihan yang berkualitas tentunya harus disesuaikan dengan kemampuan atlet yang dilatihnya, seperti program latihan yang diberikan harus sesuai dan sejalan dengan perkembangan atlet, dan dikondisikan dengan jenis kelamin dan usianya. Ada empat faktor latihan yang menjadi pusat perhatian seorang pelatih dalam menjalankan tugasnya, antara lain: (1) Fisik, (2) Teknik,

(3) taktik, dan (4) Mental, yang kesemuanya itu harus diperhatikan perkembangannya guna menciptakan atlet yang profesional dan memiliki komitmen yang tinggi, untuk meraih prestasi tinggi. Modal seorang atlet adalah perantara berupa visual, audio, dan kinestetik. Menyesuaikan dengan modalitas atlet untuk latihan maka jenis media pun dikelompokkan dalam jenis media kinestetik. media kinestetik merupakan media yang penggunaan dan pemfungsiannya memerlukan sentuhan (touching) antara pelatih dan atlet. Salah satu jenis media kinesetik adalah permainan dan simulasi, media tidak hanya berupa fisik saja, tetapi lingkungan dan suasana juga bagian dari media latihan. Kreativitas pelatih dalam latihan tentunya diharapkan menghasilkan produk yang dapat digunakan oleh atlet mencapai tujuan latihan itu salah satunya dengan menggunaan model-model yang berbeda. Sugiyono (2013:297) menyatakan, "Untuk menghasilkan produk tertentu digunakan penelitian yang bersifat analisis kebutuhan dan untuk menguji keefektifan produk tersebut supaya dapat berfungsi di masyarakat luas." Analisis kebutuhan ini berlaku dalam menetapkan model yang akan dikembangkan dalam penelitian ini agar hasilnya sesuai dengan yang diharapkan. Dalam dunia pelatihan hasil analisis tentunya diharapkan mampu memberikan jawaban mengenai apa kebutuhan atlet saat ini. Pertimbangan model ini diharapkan mencapai latihan yang efektif, efesien dan memiliki ketertarikan dalam proses latihan. Bolavoli merupakan salah satu cabang olahraga yang populer dikalangan masyarakat Indonesia, dari kalangan bawah hingga atas. Menurut Nuril Ahmadi (2007:20) mengatakan; "Bolavoli merupakan suatu permainan yang kompleks yang tidak mudah dilakukan oleh setiap orang, sebab dalam permainan bolavoli dibutuhkan koordinasi gerak yang benarbenar bisa diandalkan untuk melakukan semua gerakan yang ada dalam permainan bolavoli." Meskipun begitu hal tersebut tidak menghalangi masyarakat untuk mempelajari lebih mendalam karena ketertarikan yang terjadi di masyarakat tinggi. Kelebihan lain dari bolavoli diungkapkan juga oleh Athanasious Papageorgiou (2002:11) yang menyatakan "Volleyball is a game that is suitable for both sexes and for players of all ages and abilities and can be adapted to allow players with a physical or mental disability to play at competitive level". Permainan yang dapat dimainkan oleh laki-laki maupun perempuan bahkan untuk orang berkebutuhan khusus 
tentunya dengan disesuaikan tingkat kesulitannya dalam berkompetisi. Barbara L Vieradan Bonnie Jill Ferguson (2010:49) menyatakan kelebihan-kelebihan lain dari permainan bolavoli antara lain: (1) It is adaptable to various conditions that may present themselves, (2) It can be played with any number on a side from two, which is extremely popular in the beach game, to six. which is the number used for interscholastic, intercollegiate, junior , and club play, (3) It can be played and enjoyed by all ages and ability levels, (4) It can be played on many surfaces-grass, wood, sand, and various artificial surfaces,(5) It is an excellent co -ed activity, (6) It is an exciting spectator sport,(7) It can be played indoors or outdoors, (8) It is an extremely popular recreational activity with numerous leagues in business, community, and school intramural programs, (9)It requires few basic rules and skills, and (10) It has limited equipment needs". Berdasarkan pernyataan tersebut, permainan bolavoli memiliki kelebihan yakni dapat dimainkan dalam berbagai kondisi, permainan ini dapat dimodifikasi dengan jumlah orang (fleksibel), dapat dimainkan antar sekolah, kolega, maupun klub-klub bolavoli, selain itu dapat dimainkan oleh segala usia dan pada tingkatan kemampuan. Permainan ini dapat dilakukan di segala bentuk area lapangan, berpasir, berumput, bersemen dan sebagainya. Kelebihan lain permainan ini adalah permainan yang menakjubkan karena melalui permainan bolavoli ini dapat membangkitkan ketertarikan penonton setempat, permainan ini dapat dimainkan di luar maupun di dalam ruangan.

Permainan ini bahkan dijadikan sebagai ladang bisnis oleh sebagian masyarakat dan digunakan sebagai program intramural sekolah. Dalam permainan ini membutuhkan beberapa aturan dasar dan keterampilan yang tidak dibatasi oleh peralatan. Bahkan kita bisa menemui permainan bolavoli di lakukan antar desa atau yang dikenal dengan gala desa yang membuat permainan bolavoli begitu populer di kalangan masyarakat. Menurut Ginanjar Atmasubrata (2012:50) bolavoli adalah "olahraga permainan yang dimainkan oleh dua grup berlawanan. Masing-masing grup memiliki enam orang pemain dan terdapat pula variasi permainan bolavoli pantai yang masing-masing group hanya memiliki dua orang pemain." Permainan bolavoli yang telah ditetapkan secara jelas mengenai sarana dan prasarananya masih bisa diubah secara fleksibel dengan melihat situasi dan kondisi yang ada di sekitar masyarakat. Maka berdasarkan penjelasan teori-teori di atas maka bolavoli merupakan permainan beregu yang dimainkan oleh 6 orang masing-masing regu dengan cara bermain memasukkan bola ke daerah lawan dengan melewati net sebagai rintangan dan berusaha untuk memenangkan permainan dengan cara mematikan bola dengan cara atau teknik tertentu. Berbagai cabang olahraga memiliki perbedaan-perbedaan yang terlihat dari karakteristik masing-masing cabang olahraga yang disesuaikan dengan keterampilan-keterampilan dasar yang dimiliki oleh cabang olahragaolahraga tersebut. Teknik-teknik inilah yang digunakan untuk mencapai prestasi yang maksimal, prestasi yang maksimal tidak akan mungkin tercipta dengan baik tanpa adanya penguasaan keterampilan-keterampilan teknik dengan benar. Dieter Beutelstahl (2008:8) menjelaskan "teknik merupakan prosedur yang telah dikembangkan berdasarkan praktik dan bertujuan mencari penyelesaian suatu problema pergerakan tertentu dengan cara yang paling ekonomis dan berguna." Teknik dasar menurut Nuril Ahmadi (2007:20) menyebutkan bahwa "Teknikteknik dalam permainan bolavoli terdiri atas passing, passing bawah dan passing atas, block, dan smash." Teknik- teknik dasar yang terdapat dalam permainan bolavoli sangat mempengaruhi keterampilan seseorang dalam permainan bolavoli. Salah satu teknik dasar dalam permainan bolavoli adalah passing. Toto Subroto dan Yudiana (2010:47) menyatakan bahwa: "Passing dalam permainan bolavoli adalah istilah cara memainkan bola pertama setelah bola berada dalam permainan akibat serangan lawan, passing lawan, atau permainan net (cover spike dan cover block)." Jenis-jenis passing ada dua yaitu passing bawah dan passing atas. Dalam passing bawah terdapat tahapan-tahapan yang harus diketahui, tahapan tersebut yakni sikap permulaan, sikap pelaksanaan dan sikap akhir. Jadi passing bawah dalam permainan bolavoli adalah merupakan serangkaian gerakan mulai dari mencondongkan badan, sedikit kedepan, dengan kedua kaki ditekuk, kemudian menggenggamkan kedua tangan dengan posisi kedua lengan dan kedua ibu jari lurus sejajar tanpa menekuk kedua siku. Pada saat akan menerima atau memukul bola, langkahkan salah satu kaki kedepan sambil mengayunkan kedua lengan 
kedepan atas mendorong ke arah sasaran. Selanjutnya gerakan diakiri dengan melepaskan genggaman tangan dengan pandangan tertuju melihat arahnya bola. c. Teori kondisi fisik

Menurut Sugiyanto (1996:221), kemampuan fisik adalah kemampuan memfungsikan organ-organ tubuh dalam melakukan aktivitas fisik. Kemampuan fisik sangat penting untuk mendukung mengembangkan aktifitas psikomotor. Gerakan yang terampil dapat dilakukan apabila kemampuan fisiknya memadai. Menurut Mochamad Sajoto (1995: 8-9), kondisi fisik adalah satu kesatuan utuh dari komponen-komponen yang tidak dapat dipisahkan begitu saja, baik peningkatan maupun pemeliharaan. Artinya bahwa di dalam usaha peningkatan kondisi fisik maka seluruh komponen tersebut harus berkembang. Status kondisi fisik dapat mencapai titik optimal jika memulai latihan sejak usia dini dan dilakukan secara terus menerus dan berkelanjutan dengan berpedoman pada prinsip-prinsip dasar latihan. Status kondisi fisik seseorang dapat diketahui dengan cara penilaian yang berbentuk tes kemampuan. Tes ini dapat dilakukan di dalam labratorium dan di lapangan. Meskipun tes yang dilakukan di laboratorium memerlukan alat-alat yang mahal, tetapi kedua tes tersebut hendaknya dilakukan agar hasil penilaian benar-benar objektif. Kondisi fisik dapat mencapai titik optimal jika latihan dimulai sejak usia dini dan dilakukan secara terus menerus. Karena untuk mengembangkan kondisi fisik bukan merupakan pekerjaan yang mudah, harus mempunyai pelatih fisik yang mempunyai kualifikasi tertentu sehingga mampu membina pengembangan fisik atlet secara menyeluruh tanpa menimbulkan efek di kemudian hari. Kondisi fisik yang baik mempunyai beberapa keuntungan, di antaranya mampu dan mudah mempelajari keterampilan yang relatif sulit, tidak mudah lelah saat mengikuti latihan maupun pertandingan, program latihan dapat diselesaikan tanpa mempunyai banyak kendala serta dapat menyelesaikan latihan berat. Kondisi fisik sangat diperlukan oleh seorang atlet, karena tanpa didukung oleh kondisi fisik prima maka pencapaian prestasi puncak akan mengalami banyak kendala, dan mustahil dapat berprestasi tinggi.

Penyampaian Materi (praktek). Pengembangan model latihan diharapkan menjadi produk yang dapat dikembangkan secara sistematis dan logis, sehingga produk ini mempunyai keefektifan dan keefisienan yang layak digunakan.

Animo atlet untuk berprestasi pada cabang olahraga bolavoli sangat antusias, melihat para atletnya terdiri dari bermacam kalangan dan profesi, terkhusus kepada atlet yang ingin berprestasi, baik laki-laki maupun perempuan, dari beberapa jenjang usia, mulai dari pelajar dan mahasiswa. Pemberian materi latihan yang baik sangat dipandang perlu dilakukan, sebagai bentuk apresiasi kepada atlet guna memenuhi segala kebutuhan yang mengedepankan kondisi fisik yang prima, yang nantinya dapat mendukung segala aktifitas fisik yang terkait dengan keterampilan pada cabang olahraga bolavoli dimasa mendatang. Salah satu masalah yang paling rumit dalam kerangka pembinaan olahraga adalah masih kurang memanfaatkan sikap secara ilmiah. Bahkan sering kali latihan diselenggarakan berdasarkan kajian- kajian yang tidak tentu, terkecuali opini atau pengetahuan lainnya yang tidak teruji secara sistematik. Kurangnya konsep, teori bahkan penerapan dalam kondisi pembinaan olahraga, sementara sebagai teori masih membutuhkan pengujian lebih lanjut. Keberadaan pembinaan olahraga bolavoli dapat dilihat dari permasalahan, pembibitan dan peningkatan prestasi. Ketiga pembinaan olahraga bolavoli merupakan langkah yang perlu dijalankan untuk menjaga kelangsungan pembinaan, diawali dengan pelatihan /pembibitan mulai pada usai dini, permasalahan, maksudnya agar cabang olahraga bolavoli dapat berkembang dan digemari oleh masyarakat untuk mendapatkan pengembangan dan perhatian yang positif. Pembuatan program latihan merupakan salah satu konsep latihan untuk mencapai tujuan jangka pendek, menengah dan panjang, dalam meraih prestasi setinggi mungkin. Pelatih membuat rencana latihan berarti memilih alternatif yang tepat sebagai tuntunan yang perlu dilaksanakan untuk peningkatan prestasi sekarang ke prestasi yang akan datang sebagai sasaran yang ingin dicapai oleh atletnya. Merencanakan pelatihan yang dapat memacu para pemain untuk bermain, berlatih dan menikmati permainan adalah salah satu tugas paling utama bagi pelatih bolavoli. Pemain menginginkan dan membutuhkan suasana latihan yang mengasyikkan, tidak membosankan serta memiliki arah yang jelas terhadap materi latihan yang berkualitas. Atlet muda potensial pada umumnya lebih banyak memetik manfaat dari latihan-latihan yang menantang tapi mengasyikkan, praktek 
bermain yang penuh aktivitas, jenis, pola dan metode latihan yang membuat mereka melakukan banyak gerakan secara konstan.

\section{Hasil Dan Pembahasan}

Peserta sosialisasi model latihan passing bawah (dhindhon) dalam permainan bolavoli di Kabupaten Bantaeng. Program kemitraan ini menunjukkan bahwa masalah yang dihadapi mitra dapat terpecahkan dengan baik dan terarah. Hasil kegiatan pelaksanaan model latihan passing bawah (dhindhon) menghasilkan secara optimal peningkatan passing bawah bagi atlet tanpa mendapatkan kesulitan atau kendala-kendala dalam penerapannya. Hasil yang telah dicapai dalam kegiatan sosialisasi program kemitraan masyarakat ini adalah pengetahuan dan keterampilan tentang model latihan passing bawah (dhindhon) dalam permainan: (1) Seluruh atlet maupun pelatih memperoleh penambahan pengetahuan yang cukup tentang pentingya pengetahuan teori latihan, teori passing bawah bolavoli, teori kondisi fisik dan konsep biomekanika secara umum. Sedangkan model latihan passing bawah (dhindhon) dalam permainan bolavoli sangat bermanfaat dalam meningkatkan keterampilannya untuk dapat berinovasi dalam meningkatkan teknik passing bawah bolavoli, (2) Seluruh peserta mendapatkan tambahan pengetahuan tentang nama-nama gerakan latihan fisik dan bentukbentuk atau model gerakan latihan fisik yang efektif dengan memanfaatkan model latihan passing bawah (dhindhon) dalam permainan bolavoli di Kabupaten Bantaeng, dan (3) Seluruh peserta mendapatkan pemahaman tentang langkah-langkah dalam menerapkan bentuk atau model latihan kombinasi teknik dan kondisi fisik yang dapat diterapkan pada program latihan di klub di Kabupaten Bantaeng.

Sebagai hasil akhir dalam kegiatan pelatihan ini dilakukan evaluasi untuk mengetahui peningkatan pengetahuan dan keterampilan seluruh peserta, dilakukan sebagai berikut: (1) Evaluasi pengetahuan dari segi teori; Evaluasi ini dilakukan dengan tanya-jawab dan dalam bentuk lisan seputar teori latihan, teori kondisi fisik, teori teknik passing bawah bolavoli, dan konsep biomekanika. Hasilnya dari seluruh peserta yang mengikuti kegiatan dapat memahmi dan mengerti adanya pengetahuan dalam mencapai keterampilan untuk berprestasi pada cabang olahraga bolavoli, (2) Evaluasi keterampilan; Evaluasi keterampilan ini dilakukan melalui praktek dengan cara memperagakan model-model latihan passing bawah (dhindhon) dalam permainan bolavoli yang dikombinasikan antara teknik passing bawah dan latihan kondisi fisik mulai gerakan lengan, latihan otot perut, dan latihan tungkai sehingga pelatih dan atlet klub di Kabupaten Bantaeng dapat tercapai dalam sosialisasi PKM. Pelatih dan atlet dapat mengaplikasikannya dengan maksimal tentang kombinasi teknik passing bawah bolavoli dan latihan kondisi fisik yang dapat diaplikasikan dengan kreatifitas dan inovasi model-model latihan secara langsung, sehingga dalam setiap sesi latihan dapat diterapkan dengan baik sesuai luaran yang diharapkan pada program kemitraan masyarakat ini, dan (3) Hasil evaluasi menunjukkan terjadi peningkatan yang sangat signifikan pengetahuan tentang sains sport dan peningkatan keterampilan gerak dalam menerapakan model latihan passing bawah (dhindhon) bagi atlet yang mengikuti sosialisasi yang sesuai dengan tujuan yang diinginkan dalam pelatihan ini.

Hal- hal yang menjadi factor pendukung keberhasilan kegiatan kemitraan masyarakat ini disebabkan oleh beberapa faktor: (1) Secara organisasi klub bolavoli di Kabupaten Bantaeng adalah sebuah wadah organisasi cabang olahraga bolavoli yang menampung atlet-atlet muda yang memiliki talenta yang dibentuk oleh pembina dan pelatih untuk dapat meningkatkan keterampilan dalam permainan bolavoli, sehingga klub-klub tersebut dapat menjalin kerjasama dengan baik dengan tenaga-tenaga akademisi yang ada di Fakultas Ilmu Keolahragaan yang sesuai bidangnya, (2) Para peserta sosialisasi adalah atlet sangat membutuhkan pemahaman dan pengetahuan tentang pentingnya program-program latihan dengan berbagai metode dan model untuk meningkatkan keterampilan melalui kombinasi latihan teknik dan latihan kondisi fisik, (3) Semangat dan antusias para peserta, menjadikan kegiatan ini dapat berlangsung dengan baik dan manfaatnya dirasakan secara langsung oleh peserta, (4) Pengalaman yang dimiliki baik sebagai atlet dan pelatih oleh Tim khususnya yang melaksanakan PKM dapat 
mempermudah dan sehingga tidak terlalu sulit untuk menjelaskan model latihan dhindhon, dan (4) Sarana dan prasarana yang ada sehingga atlet atau peserta dapat menggunakan dengan maksimal dalam memperagakan atau mempraktekkan model latihan dhindhon.

Kegiatan kemitraan masyarakat tentunya tidak terlepas dengan kendala atau hambatan. Beberapa factor penyebabnya antara lain: (1) Prasarana dalam hal ini lapangan bolavoli yang dimiliki masih bersifat outdoor sehingga peserta atau atlet yang mengikuti sosialisasi terbatas dalam melakukan model latihan passing bawah, (2) Terik matahari yang sangat panas sehingga peserta hanya memiliki waktu yang terbatas dalam memperagakan model latihan, dan (3) Jenis pakaian dan sepatu yang digunakan belum sesuai dalam kategori sebagai pemain atau atlet sebab akan mempengaruhi gerak yang dilakukan tidak maksimal.

Menjelaskan tentang hasil atau luaran pengabdian bisa berupa peningkatan pengetahuan, keterampilan atau berupa produk. Hasil juga mengemukakan tingkat ketercapaian target kegiatan. Jika berupa benda perlu ada penjelasan spresifikasi produk, keunggulan dan kelemahannya. Penulisan luaran perlu dilengkapi foto, tabel, grafik, bagan, gambar dsb. Pembahasan berurut sesuai dengan urutan dalam tujuan, dan sudah dijelaskan terlebih dahulu. Pembahasan disertai argumentasi yang logis dengan mengaitkan hasil PkM dengan teori, hasil PkM yang lain dan atau hasil penelitian.
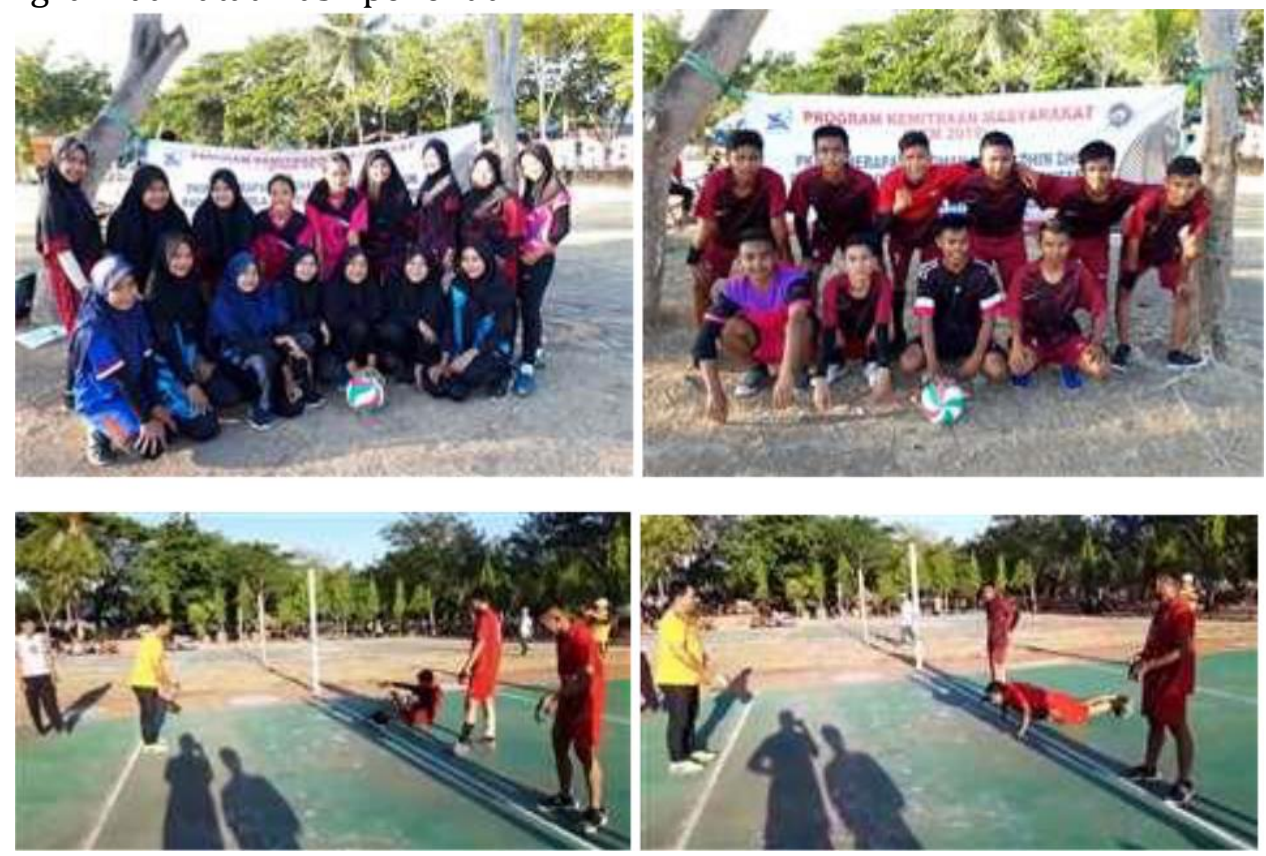

Gambar 1: Tim Memberikan Materi dalam Pelatihan

\section{Simpulan Dan Saran}

Pelaksanaan kegiatan sosialsiasi model latihan passing bawah (dhindhon) dalam permainan bolavoli di Kabupaten Bantaeng dapat ditarik kesimpulan sebagai berikut: (1) Pada umumnya peserta sosialisasi sangat antusias dalam menerima materi yang diberikan baik secara teori maupun praktek, (2) Peserta dapat menyadari bahwa untuk mendapatkan kterampilan atau skill yang maksimal dibutuhkan program latihan dengan berbagai metode dan model latihan yang dilakukan secara sistematis dan terprogram, dan (3) Adanya sosialisasi model latihan passing bawah (dhindhon) dalam permainan bolavoli sangat membantu untuk mencapai keterampilan teknik secara maksimal yang selama hanya dilakukan secara konvensional tanpa adanya kreatifitas dan inovasi setiap latihan.

Berdasarkan hasil pelaksanaan sosialisasi di Kabupaten Bantaeng tentang model latihan passing bawah (dhindhon) dalam permainan bolavoli, maka dapat ditraik beberapa saran diantaranya: (1) Agar supaya pemerintah daerah di Kabupaten Bantaeng memiliki GOM (Gedung Olahraga Masyarakat) di setiap kecamatan untuk dapat dimanfaatkan sebagai prasarana yang 
dapat digunakan sebagai multifungsi khususnya cabang olahraga bolavoli yang saat ini harus untuk menggunakan lapangan indoor, (2) Diupayakan adanya kerjasama yang baik antara Pemerintah Daerah Kabupaten Bantaeng dan Fakultas Ilmu Keolahragaan dalam meningkatkan prestasi olahraga, (3) Diharapkan agar dalam pelaksanaan latihan bolavoli untuk dapat menerapkan program latihan yang berdasar secara ilmiah, (4) Perlunya menguprage kembali setiap pelatih tentang ilmu yang dimiliki untuk dapat meningkatkan kreatifitas dan berinovasi dalam melatih guna mencapai hasil prestasi maksimal, dan (5) Hasil sosialisasi yang di laksanakan di Kabupaten Bantaeng dapat berkelanjutan dan dilaksanakan di Kabupaten lain melalui Pengabdian Kepada Masyarakat maupun pelatihan.

\section{Daftar Rujukan}

Ahmadi, Nuril. 2007. Panduan Olahraga Bolavoli. Surakarta: Era Pustaka Utama.

Atmasubrata, Ginanjar. 2012. Serba Tahu Dunia Olahraga. Surabaya: Dafa Publishing.

Beutelstahl, Dieter. 2008. Belajar Bermain Bola Volley. Bandung: Pionir Jaya.

Engkos Kosasih. 1985. Olahraga Teknik dan Program Latihan. Jakarta: Akademika Pressindo.

HP, Suharno. 1984. Dasar-dasar Permainan Bola Voli. Yogyakarta: IKIP.

Jim Lavin. 2008. Creative Approaches to Physical Education Helping Children to Achieve Their True Potensial. Canada. Routledge.

Imam Hidayat. 1996. Biomekanika. Bandung: FPOK IKIP.

McGinnis, Peter M. 2005. Biomechanis of Sport and Exercise (Second Edition).

Papageorgiou, Athanasious. 2002. Volleyball a Handbook For Choach and Player. USA: Meyer and Meyer Sport.

Pete, Waite. 2009. Aggresive Volleyball, Dictate The Pace, Determine Outcome. USA:Human Kinetics.

Subroto, Toto dan Yunyun Yudiana. 2010. Permainan Bolavoli. Bandung: Universitas Pendidikan Indonesia.

Sugiyono. 2013. Metode Penelitian Kuantitatif, Kualitatif dan R \& D. Bandung: Alfabeta.

Viera, Barbara L dan Bonnie Jill Fergusson. 2000. Bolavoli Tingkat Pemula. Jakarta: Raja Grafindo Persada.

Viera, Barbara L, \& Bonnie Jill Ferguson. 2004. Bola voli terjamahan Monti. Jakarta: PT Raja Grafindo.

Viera, Barbara L, \& Bonnie Jill Ferguson. 2010. Volleyball Step To Succes Second Edition. Canada:Human Kinetics.

Yunus, M. 1992. Olahraga Pilihan Bola Voli. Jakarta: Depdikbud, Dirjen Dikti. 